\title{
Kesantunan berbahasa para kader posyandu dalam pelaksanaan layanan informasi
}

\author{
Endang Wiyanti a, 1, ${ }^{*}$, Yulian Dinihari ${ }^{b, 2}$, Solihatun ${ }^{c, 3}$ \\ a Pendidikan Bahasa dan Sastra Indonesia, FBS, Universitas Indraprasta PGRI \\ ${ }^{\mathrm{b}}$ Pendidikan Biologi, FMIPA, Universitas Indraprasta PGRI \\ c Bimbingan dan Konseling, FIPPS, Universitas Indraprasta PGRI \\ 1 endangwiyanti76@gmail.com *; ${ }^{2}$ yuliandini07@gmail.com; ${ }^{3}$ solihatunsolie@gmail.com \\ *korespondensi penulis
}

\begin{tabular}{ll}
\hline Informasi artikel & \\
\hline Sejarah artikel: & \\
Diterima & I2 Desember 2018 \\
Revisi & I8 Maret 2019 \\
Dipublikasikan & I5 April 2019 \\
\hline
\end{tabular}

Kata kunci:

Kader Posyandu

Kesantunan berbahasa

Tindak tutur

\begin{abstract}
ABSTRAK
Tujuan penelitian ini adalah (I) mendeskripsikan jenis tindak tutur para kader Posyandu Mawar VII dan Posyandu Mawar IX Pademangan Barat Jakarta Utara dalam proses layanan informasi. (2) mendeskripsikan prinsip kesantunan berbahasa kader Posyandu Mawar VII dan Posyandu Mawar IX Pademangan Barat Jakarta Utara pada saat proses layanan informasi berlangsung. Data yang digunakan dalam penelitian ini adalah lisan dan tulisan. Data lisan dan tulisan diperoleh dengan cara merekam dan mencatat ujaran-ujaran para kader pada saat melakukan layanan informasi. Teknik pengumpulan data dalam penelitian ini dilakukan dengan teknik simak bebas libat cakap, teknik rekam, dan teknik catat. Hasil penelitian ini adalah para kader lebih banyak melakukan tindak tutur santun dengan menggunakan tuturan direktif, representatif, komisif, ekspresif, dan deklarasi. Kedua, para kader menggunakan empat maksim, yaitu (I) maksim kearifan, (2) maksim kedermawanan, (3) maksim pujian, dan (4) maksim pemufakatan.
\end{abstract}

Key word:

Posyandu cadres

Language politeness

Speech act

\begin{abstract}
The purpose of this study was (I) to describe the type of speech acts of Posyandu cadres Mawar VII and Posyandu Mawar IX Pademangan Barat North Jakarta in the information service process. (2) describe the principle of courtesy in Posyandu Mawar VII and Posyandu Mawar IX Pademangan Barat North Jakarta when the information service process takes place. The data used in this study are oral and written. Oral and written data is obtained by recording and recording the utterances of the cadres when carrying out information services. Data collection techniques in this study were carried out by referring to proficient free technique, recording techniques, and note taking techniques. The results of this study are that cadres do more polite speech acts using directive, representative, commissive, expressive, and declaration speeches. Second, cadres use four maxims, namely (I) wisdom maxim, (2) generosity maxim, (3) praise maxim, and (4) consensus maxim.
\end{abstract}

Copyright (C) 2019 Universitas Ahmad Dahlan

\section{Pendahuluan}

Kesantunan (politiness), kesopansantunan, atau etika adalah tata cara, adat, atau kebiasaan yang berlaku dalam masyarakat. Kesantunan merupakan aturan perilaku yang ditetapkan dan disepakati bersama oleh suatu masyarakat tertentu sehingga kesantunan sekaligus menjadi prasyarat yang disepakati oleh perilaku sosial. Manusia dalam kehidupannya memerlukan komunikasi untuk dapat menjalin hubungan dengan manusia lain dalam lingkungannya. Tujuan manusia berkomunikasi adalah untuk menyampaikan pesan dan menjalin hubungan sosial. Komunikasi untuk menjalin hubungan sosial dilakukan dengan menggunakan beberapa strategi. Posyandu memiliki andil dalam membentuk kesantunan berbahasa para ibu rumah tangga di masyarakat karena mereka yang akan membentuk karakter dalam keluarga. Bahasa yang santun diduga dapat meredam amarah dan rasa kecewa dan dapat membuat situasi tetap terkendali. Akan tetapi, tidak dapat dipungkiri bahwa pada kenyataannya masih ada kader yang kurang memerhatikan prinsip kesantunan dalam bertutur. Berdasarkan observasi peneliti di (Pos Pelayanan Terpadu (Posyandu) Mawar VII dan Posyandu 
Mawar IX Pademangan Barat Jakarta Utara dan hasil wawancara peneliti dengan para kader tersebut, serta pengalaman peneliti sendiri sebagai ibu rumah tangga, peneliti menemukan bahwa para kader lebih sering menggunakan tindak tutur langsung atau perintah.

Berdasarkan temuan tersebut, peneliti ingin mengetahui tuturan yang digunakan para kader Posyandu Mawar VII dan Posyandu Mawar IX Pademangan Barat Jakarta Utara dalam proses layanan informasi serta bagaimana prinsip kesantunan yang digunakan para kader dalam bertutur untuk menjaga citra kader tersebut di depan masyarakat setempat dan menjaga citra dirinya di depan kader yang lain. Hal ini terjadi karena setiap orang ingin dihormati dan tidak ingin dilecehkan atau direndahkan baik melalui bahasa maupun sikap.

Berdasarkan uraian di atas, tujuan penelitian ini ada dua. Pertama, mendeskripsikan jenis tindak tutur para kader Posyandu Mawar VII dan Posyandu Mawar IX Pademangan Barat Jakarta Utara dalam proses layanan informasi. Kedua, mendeskripsikan prinsip kesantunan berbahasa guru Bahasa Indonesia Posyandu Mawar VII dan Posyandu Mawar IX Pademangan Barat Jakarta Utara pada saat proses layanan informasi berlangsung.

Kesantunan berbahasa sudah banyak dikaji dan dibahas. Berikut beberapa referensi dan penelitian yang relevan dengan kesantunan berbahasa. Hasil penelitian Budiwati (2017) menunjukkan bahwa bentuk-bentuk kesantunan berbahasa mahasiswa UAD dalam media sosial adalah Muka Positif dan Muka Negatif; terdapat pematuhan dan penyimpangan terhadap beberapa maksim, seperti Maksim Kebijaksanaan, Maksim Kedermawanan, Maksim Penerimaan, Maksim Persetujuan, dan Maksim Simpati; terdapat fungsi-fungsi kesantunan berbahasa, seperti Fungsi Representatif, Fungsi Direktif, Fungsi Ekspresif, dan Fungsi Komisif.

Kajian strategi kesopanan pada dasarnya adalah kajian tentang mengetahui cara menggunakan bahasa ketika partisipan sedang berinteraksi atau berkomunikasi. Kajian ini membahas bagaimana menggunakan bahasa dan membuat percakapan berjalan lancar dan nyaman. Akan tetapi, dalam hal komunikasi setiap orang ingin dipahami dan tidak ingin diganggu oleh orang lain. Bahkan, dia tidak ingin kehilangan muka pada saat berkomunikasi. Kehilangan muka berarti merasa malu, terhina atau kecewa. Itulah mengapa muka adalah sesuatu yang secara emosional diinvestasi, dijaga, ditingkatkan, dan secara konstan ada di dalam interaksi (Wijaya, 2015).

Kajian tentang kesantunan dalam berbahasa erat dengan kajian pragmatik. Pragmatik adalah cabang linguistik yang berhubungan dengan penggunaan bahasa dalam konteks sosial dan cara-cara yang digunakan pengguna bahasa untuk memproduksi dan memahami makna melalui bahasa (Nordquist, 2015). Pragmatik berkaitan dengan karakteristik perilaku pengguna bahasa (saat berbicara). Salah satu kajian pragmatik adalah kesopanan atau kesantunan.

Kesantunan memiliki makna yang berbeda dengan kesopanan. Kata sopan memiliki arti menunjukkan rasa hormat pada mitra tutur, sedangkan kata santun memiliki arti berbahasa (atau berperilaku) dengan berdasarkan pada jarak sosial antara penutur dan mitra tutur. Konsep wajah di atas benar-benar berkaitan dengan persoalan kesantunan dan bukan kesopanan. Rasa hormat yang ditunjukkan melalui berbahasa mungkin berakibat santun, artinya, sopan berbahasa akan memelihara wajah jika penutur dan mitra tutur memiliki jarak sosial yang jauh (misalnya antara dosen dan mahasiswa, atau anak dan ayah). Meskipun demikian, bersikap santun dalam berbahasa seringkali tidak berakibat sopan, terlebih lagi jika penutur dan mitra tutur tidak memiliki jarak sosial yang jauh (teman sekerja, konco, pacar, dan sebagainya).

Yule (2006) mengatakan bahwa kesantunan dalam suatu interaksi dapat didefinisikan sebagai alat yang digunakan untuk menunjukkan kesadaran tentang muka orang lain. Menurut Brown dan Levinson (1987), yang terinspirasi oleh Goffman (1967), bahwasanya bersikap santun itu adalah bersikap peduli pada "wajah" atau "muka," baik milik penutur, maupun milik mitra tutur. "Wajah," dalam hal ini bukan dalam arti rupa fisik, namun "wajah" dalam artian public image, atau mungkin padanan kata yang tepat adalah "harga diri" dalam pandangan masyarakat. Konsep wajah ini berakar dari konsep tradisional di Cina, yang dikembangkan oleh Konfusius terkait dengan nilai-nilai kemanusiaan (Aziz, 2008). Pada wajah, dalam tradisi Cina, melekat atribut sosial yang merupakan harga diri, sebuah penghargaan yang diberikan oleh masyarakat, atau dimiliki secara individu. Wajah, merupakan "pinjaman masyarakat," sebagaimana sebuah gelar akademik yang diberikan oleh sebuah perguruan tinggi, yang kapan saja bisa ditarik oleh yang memberi. Oleh karena itu, si pemilik wajah itu haruslah berhati-hati dalam berprilaku, termasuk dalam berbahasa.

Kesantunan berbahasa adalah kesopanan dan kehalusan dalam menggunakan bahasa ketika berkomunikasi melalui lisan atau tulisan. Bahasa yang digunakan penuh dengan adab tertib, sopan santun dan mengandungi nilai-nilai hormat yang tinggi. Kesantunan berbahasa, menurut Markhamah (20II), merupakan cara yang digunakan oleh penutur di 
dalam berkomunikasi agar mitra tutur tidak merasa tertekan, tersudut, atau tersinggung. Kesantunan berbahasa dimaknai sebagai usaha penutur untuk menjaga harga diri, atau wajah, penutur atau pendengar. Menurut Syahrul (2008), "Kesantunan merupakan suatu sistem hubungan interpersonal yang dirancang untuk mempermudah interaksi dengan memperkecil potensi konflik dan konfrontasi yang selalu terjadi dalam pergaulan manusia”. Brown dan Levinson (2013) mengartikan kesantunan sebagai melakukan tindakan yang mempertimbangkan perasaan orang lain yang di dalamnya memerhatikan positive face (muka positif) yaitu keinginan untuk diakui dan negative face (muka negatif), yaitu keinginan untuk tidak diganggu dan terbebas dari beban.

Menurut Uddin (2015), teori kesantunan berbahasa banyak dipengaruhi oleh konsep muka (face) yang dikemukakan oleh Brown dan Levinson (1987). Menurut Brown dan Levinson, muka mengacu kepada citra diri. Muka atau citra diri seseorang dapat jatuh. Oleh karena itu, muka perlu dijaga atau dilindungi. Agar muka tidak jatuh, muka perlu dijaga baik oleh pemilik muka itu sendiri maupun orang lain yang sedang berkomunikasi. Salah satu faktor yang berpotensi untuk menjatuhkan muka pelaku tutur adalah tindak tutur, tindak tutur perlu dilengkapi dengan peranti penyelamat muka yang berupa kesantunan berbahasa. Muka dikelompokkan menjadi dua, yaitu muka positif (positive face) dan muka negatif (negative face).

a. Muka Positif (Positive Face)

Sebagaimana telah disebutkan bahwa wajah positif berkaitan dengan nilai-nilai keakraban antara penutur dan mitra tutur.

Maksud dari mengancam wajah (face threatening) adalah mengancam jati diri sebagai sahabat dekat, konco, dan sebagainya. Isu sentral dari mengancam wajah adalah kerenggangan jarak sosial yang diakibatkan oleh penggunaan bahasa yang relatif tidak santun, atau tidak memenuhi kaidahkaidah konsep wajah positif.

b. Muka Negatif (Negative Face)

Berbeda dengan wajah positif, yang mana penutur dan mitra tutur mengharapkan terjaganya nilai-nilai keakraban, ketakformalan, kesekoncoan, maka wajah negatif ini adalah situasi ketika penutur dan mitra tutur mengharapkan adanya jarak sosial.

c. Pengancaman Muka (Face Threatening Act)

Sebagaimana telah dijelaskan dengan berbagai contoh, kesantunan (dan kesopanan) berbahasa dapat diartikan sebagai sebuah penunjukkan mengenai kesadaran terhadap wajah orang lain (Yule, 2006). Wajah seseorang akan mengalami ancaman ketika seorang penutur menyatakan sesuatu yang mengandung ancaman terhadap harapan-harapan individu yang berkenaan dengan nama baiknya sendiri.

Pengancaman wajah melalui tindak tutur (speech act) akan terjadi jika penutur dan mitra tutur sama-sama tidak berbahasa sesuai dengan jarak sosial. Respons dari mitra tutur muda merupakan tindak penyelamatan wajah (face saving act); yaitu dengan cara melakukan kesantunan negatif dengan mengeluarkan pernyataan yang menunjukkan kesadaran atas jarak sosial dan wajah negatif penutur tua. Artinya, mitra tutur muda menyadari keinginan wajah penutur tua untuk merdeka dan memiliki hak untuk tidak terganggu. Pengancaman terhadap wajah ini juga bersifat positif dan juga negatif. Jika penutur dan mitra tutur memiliki jarak sosial dekat, maka pengancaman wajah bersifat negatif. Sementara itu, jika penutur dan mitra tutur memiliki jarak sosial yang jauh, maka pengancaman wajah bersifat positif.

Wajah positif terkait dengan nilai solidaritas, ketakformalan, pengakuan, dan kesekoncoan. Sementara itu, wajah negatif bermuara pada keinginan seseorang untuk tetap mandiri, bebas dari gangguan pihak luar, dan adanya penghormatan pihak luar terhadap kemandiriannya itu (Aziz, 2008: 2). Melihat bahwa wajah memiliki nilai seperti yang telah disebutkan, maka nilai-nilai itu patut untuk dijaga. Salah satu caranya adalah melalui pola berbahasa yang santun, yang tidak merusak nilai-nilai wajah itu. Jadi, wajah positif adalah keinginan partisipan untuk diterima oleh mitra tutur sebagaimana kedekatan sosial antara mereka; wajah negatif adalah keinginan untuk bebas dari interfensi, tekanan, atau gangguan dari pihak lain, termasuk mitra tutur. Jika keinginan wajah positif tidak tercapai dalam bertutur, maka ancamannya pada wajah positif dan jika keinginan wajah negatif tidak tercapai, ancamannya pada wajah negatif. Konsekuensi logis dari ancaman wajah ini adalah kehilangan wajah (loosing face), atau dengan istilah sederhana adalah malu atau hilang harga diri.

Yule (2006) mengemukakan bahwa kesantunan dalam suatu interaksi dapat didefinisikan sebagai alat yang digunakan untuk menunjukkan kesadaran tentang muka orang lain. Menurut Brown dan Levinson (1987), yang terinspirasi oleh Goffman (1967), bahwasanya bersikap santun itu adalah bersikap peduli pada "wajah" atau "muka," baik milik penutur, maupun milik mitra tutur. "Wajah," dalam hal, ini bukan dalam arti rupa fisik, namun "wajah" dalam artian public image, atau mungkin padanan kata yang tepat adalah "harga diri" dalam pandangan masyarakat. Pada wajah, dalam tradisi Cina, melekat atribut sosial yang merupakan harga diri, sebuah penghargaan yang diberikan oleh 
masyarakat, atau dimiliki secara individu. Wajah, merupakan "pinjaman masyarakat," sebagaimana sebuah gelar akademik yang diberikan oleh sebuah perguruan tinggi, yang kapan saja bisa ditarik oleh yang memberi. Oleh karena itu, si pemilik wajah itu haruslah berhati-hati dalam berprilaku, termasuk dalam berbahasa.

Leech (1993) mengelompokkan prinsip kesantunan menjadi enam maksim, yaitu (I) maksim kearifan, (2) maksim kedermawanan, (3) maksim pujian, (4) maksim kerendahan hati, (5) maksim pemufakatan, dan (6) maksim simpati. Sementara, menurut Searle (dalam Gunarwan, 1994) ada lima jenis tindak tutur, yaitu (I) representatif, (2) direktif, (3) ekspresif, (4) komisif, dan (5) deklarasi. Menurut Sofa (20II), tindak tutur representatif disebut juga tindak tutur asertif, yaitu tindak tutur yang mengikat penuturnya kepada kebenaran atas apa yang dikatakannya (misalnya: menyatakan, melaporkan, menunjukkan, menyebutkan). Tindak tutur direktif disebut juga tindak tutur impositif dimaksudkan untuk menimbulkan beberapa efek dari lawan tutur. Sofa (20II) melanjutkan, ekspresif adalah tindak tutur yang dilakukan dengan maksud agar ujarannya diartikan sebagai evaluasi tentang hal yang disebutkan di dalam ujaran tersebut (misalnya: memuji, mengucapkan terima kasih, mengkritik, mengeluh). Komisif, yaitu tindak tutur yang mengikat penuturnya untuk melaksanakan apa yang disebutkan di dalam ujarannya (misalnya: berjanji, bersumpah, mengancam). Deklarasi, yaitu tindak tutur yang dilakukan si penutur dengan maksud untuk menciptakan hal (status, keadaan dan sebagainya) yang baru (misalnya: memutuskan, membatalkan, melarang, mengizinkan, memberi maaf).

Rustono (1999) juga mengungkapkan teori kesantunan yang lebih mendasarkan pada prinsip kesantunan (politeness principle), yaitu yang mencakup sejumlah bidal atau pepatah yang berisi nasihat yang harus dipatuhi agar tuturan menjadi lebih santun yaitu, (I) biaya (cost) dan keuntungan (benefit), (2) celaan atau penjelekan (dispraise) dan pujian (praise), (3) kesetujuan (agreement) serta (4) kesimpatian dan keantipatian (simpathy/antipathy). Sebagai retorika tekstual pragmatik membutuhkan prinsip kerja sama (cooperative principle), yaitu prinsip kesopanan (politeness principle). Prinsip kesopanan memiliki sejumlah bidal yaitu bidal kebijaksanaan (tact maxim), maksim kemurahan (generosity maxim), maksim penerimaan (approbation maxim), maksim kerendahatian (modesty maxim), maksim kecocokan (agreement maxim), dan maksim kesimpatian (simpathy maxim). Prinsip kesopanan ini berhubungan dengan dua peserta percakapan, yaitu diri sendiri (self) dan orang lain (other). Diri sendiri adalah penutur, dan orang lain adalah lawan tutur dan orang ketiga yang dibicarakan penutur dan lawan tutur (Wijana, 1996).

\section{Metode}

Penelitian ini merupakan penelitian deskriptif kualitatif. Metode ini dipilih karena dapat memberikan gambaran secermat mungkin mengenai individu, keadaan bahasa, gejala, atau kelompok tertentu. Teknik yang digunakan dalam pengumpulan data adalah teknik simak bebas libat cakap, teknik rekam, dan teknik catat. Pendekatan yang digunakan dalam penelitian ini adalah pendekatan pragmatik. Pragmatik adalah suatu tindakan yang dikaitkan dengan konteks situasi tutur yang melatarbelakanginya. Peneliti memilih pendekatan ini karena menelaah bahasa tulisan tentang kesantunan berbahasa para kader Posyandu ketika berinteraksi dengan para ibu dalam memberikan layanan informasi.

Data penelitian ini adalah tuturan lima orang kader Posyandu Mawar VII dan Posyandu Mawar IX Pademangan Barat Jakarta Utara dalam proses layanan informasi. Entri yang diteliti adalah kesantunan berbahasa para kader tersebut. Data diperoleh secara langsung dengan merekam dialog atau tuturan guru tersebut saat proses layanan informasi berlangsung. Selanjutnya rekaman ditranskrip dengan teknik catat dan diklasifikasi. Data yang telah dikumpulkan akan diklasifikasikan berdasarkan bentuk, prinsip, dan fungsi kesantunan berbahasa berdasarkan analisis pragmatik untuk memahami konteks dan mempertimbangkan makna kata, maksud penutur, dan fenomena kesantunan berbahasa.

\section{Hasil dan pembahasan}

Hasil penelitian ini dikelompokkan menjadi dua, yaitu (I) jenis tindak tutur kader dalam proses di Posyandu Mawar VII dan Posyandu Mawar IX Pademangan Barat Jakarta Utara dan (2) kesantunan berbahasa para kader dalam proses layanan informasi di Posyandu Mawar VII dan Posyandu Mawar IX Pademangan Barat Jakarta Utara.

I. Jenis Tindak Tutur Kader dalam Layanan Informasi di Posyandu Mawar VII dan Posyandu Mawar IX Pademangan Barat Jakarta Utara

Hasil penelitian terkait dengan jenis tindak tutur ditabulasikan dalam tabel $\mathrm{I}$. 
Tabel I. Tabulasi jenis tindak tutur kader dalam proses layanan informasi di posyandu

\begin{tabular}{llll}
\hline No. & \multicolumn{1}{c}{ Jenis Tuturan } & Jumlah \\
\hline I. & Tindak Tutur Direktif & & \\
I.I & Bertanya & 35 & tuturan \\
I.2 & Memohon & 55 & tuturan \\
I.3 & Menantang & 2 & tuturan \\
I.4 & Menuntut & 2 & tuturan \\
I.5 & Menyarankan & 8 & tuturan \\
I.6 & Menyuruh & 68 & tuturan \\
2. & Tindak Tutur Representatif & & \\
2.I & Melaporkan & 5 & tuturan \\
2.2 & Menjelaskan & I2 & tuturan \\
2.3 & Menunjukkan & 6 & tuturan \\
2.4 & Menyatakan & I0 & tuturan \\
3. & Tindak Tutur Komisif & & \\
3.I & Berjanji & 7 & tuturan \\
3.2 & Mengancam & 2 & tuturan \\
4. & Tindak Tutur Ekspresif & & \\
4.I & Memuji & 5 & tuturan \\
4.2 & Mengeluh & 2 & tuturan \\
5. & Tindak Tutur Deklarasi & & \\
5.I & Melarang & 8 & tuturan \\
5.2 & Membenarkan & 24 tuturan \\
5.3 & Mengizinkan & 4 & tuturan \\
& Jumlah & 254 tuturan \\
\hline & & & \\
\hline
\end{tabular}

Berdasarkan hasil analisis data, diperoleh peringkat jenis tindak tutur yang digunakan kader Posyandu Mawar VII dan Posyandu Mawar IX Pademangan Barat Jakarta Utara dalam proses layanan informasi. Tindak tutur direktif menduduki peringkat pertama dengan jumlah 170 tuturan $(66,92 \%)$. Peringkat kedua adalah tindak tutur representatif dengan jumlah 36 tuturan (I4,18\%). Peringkat ketiga adalah tindak tutur deklarasi dengan jumlah 32 tuturan (12,60\%). Peringkat keempat adalah tindak tutur komisif dengan jumlah 9 tuturan (3,55\%). Terakhir, peringkat kelima adalah tindak tutur ekspresif dengan jumlah 7 tuturan $(2,75 \%)$. Untuk lebih jelasnya, hasil analisis data jenis tindak tutur yang digunakan kader dalam proses layanan informasi di Posyandu Mawar VII dan Posyandu Mawar IX Pademangan Barat Jakarta Utara dapat dilihat pada Tabel I.

Berikut gambaran jenis tindak tutur para kader dalam proses layanan informasi di Posyandu Mawar VII dan Posyandu Mawar IX Pademangan Barat Jakarta Utara.

\section{a. Tindak Tutur Direktif}

Ditinjau dari segi fungsi, tindak tutur direktif yang digunakan para kader dalam proses layanan informasi dapat diklasifikasikan atas lima macam tindak tutur, yaitu (I) menyuruh, (2) bertanya, (3) menyarankan, (4) memohon, (5) menuntut, dan (6) menantang.

\section{1) Tindak Tutur Menyuruh}

Tuturan-tuturan berikut ini merupakan contoh tindak tutur menjelaskan.

(1) Silakan duduk ibu-ibu!

Informasi indeksal: dituturkan oleh kader kepada beberapa ibu yang belum menempati kursi yang telah disediakan. Tuturan I merupakan tindak tutur menyuruh. Penanda tindak tutur menyuruh adalah duduk.

\section{2) Tindak Tutur Bertanya}

Tindak tutur bertanya yang digunakan para kader Posyandu Mawar VII dan Posyandu Mawar IX Pademangan Barat Jakarta Utara dapat dilihat pada tuturan berikut.

(2) Ibu-ibu, mengerti?

Informasi indeksal: dituturkan oleh kader kepada para ibu yang hadir apakah mengerti dengan penjelasan yang diterangkan oleh kader tersebut.

Tuturan tersebut menyatakan bahwa penutur bertanya kepada lawan tutur apakah lawan tutur mengerti dengan penjelasan yang diberikan penutur.

\section{3) Tindak Tutur Menyarankan}

Tindak tutur menyarankan yang digunakan guru dalam kelas penelitian ini terlihat dari tuturan berikut.

\section{(3) Kalau ada yang kurang jelas boleh} ditanyakan kembali.

Informasi indeksal: dituturkan oleh kader kepada peserta yang hadir mempersilakan bertanya apabila ada hal yang kurang jelas. Kata boleh yang dituturkan kader kepada ibu-ibu adalah tuturan untuk menyarankan agar apa yang disarankan itu dilakukan oleh peserta.

\section{4) Tindak Tutur Memohon}

Tindak tutur memohon ini terdapat pada tuturan berikut.

(4) Pangkulah anaknya Bu, supaya ibu bisa fokus mendengarkan penjelasan!

Informasi indeksal: dituturkan oleh kader kepada para ibu yang anaknya berkeliaran sehingga mengganggu konsentrasi para ibu dalam memahami penjelasan dari para kader.

Tuturan 4 adalah tindak tutur memohon, penandanya adalah kata pangkulah. Pada tuturan tersebut kader memohon kepada para ibu agar memangku anaknya selama penjelasan berlangsung.

\section{5) Tindak Tutur Menuntut}

Tindak tutur ini terdapat pada tuturan kader Posyandu Mawar VII dan Posyandu Mawar IX Pademangan Barat Jakarta Utara berikut ini.

(5) Mana kartu sehatnya, ibu sayang? 
Informasi indeksal: dituturkan oleh kader kepada seorang ibu yang mengatakan kartu sehat sudah dibawa, namun tidak dapat menunjukkannya kepada kader.

Pada tuturan tersebut kader menuntut seorang ibu untuk membuktikan bahwa memang ibu tersebut membawa kartu sehat.

\section{6) Tindak Tutur Menantang}

Tindak tutur menantang yang ditemukan dalam penelitian ini ada satu tuturan, yaitu sebagai berikut.

(6) Kalau kartu sehat tidak dibawa, saya tidak bisa catat perkembangan anak ibu.

Informasi indeksal: dituturkan oleh kader kepada seorang ibu agar lain kali tidak lupa membawa kartu sehat sang anak.

Pada tuturan tersebut kader menyuruh para ibu membawa kartu sehat tiap datang ke Posyandu. Dilihat dari segi makna, tuturan tersebut cenderung menantang lawan bicaranya untuk tidak mencatat perkembangan anaknya jika tidak ada kartu sehat.

\section{b. Tindak Tutur Representatif}

Tindak tutur representatif yang ditemukan dalam tuturan kader Posyandu Mawar VII dan Posyandu Mawar IX Pademangan Barat Jakarta Utara ini dari segi fungsi ada empat macam, yaitu (I) tindak tutur menyatakan, (2) tindak tutur menjelaskan, (3) tindak tutur menunjukkan, dan (4) tindak tutur melaporkan.

\section{1) Tindak Tutur Menyatakan}

Tindak tutur menyatakan yang digunakan oleh kader Posyandu Mawar VII dan Posyandu Mawar IX Pademangan Barat Jakarta Utara ini dapat dilihat pada tuturan berikut.

(7) Vitamin A.

Informasi indeksal: dituturkan oleh kader kepada para ibu yang menyebutkan salah satu vitamin yang akan dibagikan kepada para ibu yang hadir untuk diberikan kepada anak balitanya.

Pada tuturan tersebut penutur menyatakan bahwa apa yang disebutkan oleh para ibu adalah suplemen anak berupa vitamin yang akan dibagikan oleh Posyandu.

\section{2) Tindak Tutur Menjelaskan}

Tuturan berikut ini merupakan contoh tindak tutur yang digunakan kader Posyandu Mawar VII dan Posyandu Mawar IX Pademangan Barat Jakarta Utara.

(8) Imunisasi yang wajib diberikan pada anak ada 5, yaitu Hepatitis B, Polio, BCG, Campak, dan Pentavalen (DPT, HB, HiB) dan perlu diulang di usia tertentu.

Informasi indeksal: dituturkan oleh kade kepada salah seorang ibu yang menyatakan imunisasi bagi anak sekali seumur hidup.
Tuturan tersebut menyatakan bahwa si penutur menjelaskan kepada salah seorang ibu bahwa apa yang telah dinyatakan oleh ibu tersebut betul, tetapi imunisasi tersebut akan ada pengulangan kembali pada usia tertentu.

\section{3) Tindak Tutur Menunjukkan}

Tindak tutur menunjukkan yang digunakan kader dapat dilihat pada tuturan berikut.

(9) Seperti ini cara memberikan vitaminnya.

Informasi indeksal: dituturkan oleh kader kepada para ibu bagaimana cara memberikan vitamin kepada anaknya.

Tuturan tersebut menyatakan bahwa si penutur memberitahukan para ibu bahwa cara memberikan vitamin cukup diteteskan saja.

\section{4) Tindak Tutur Melaporkan}

Berikut contoh tuturan melaporkan yang digunakan kader Posyandu Mawar VII dan Posyandu Mawar IX Pademangan Barat Jakarta Utara

\section{(10) Beberapa orang yang tidak hadir dengan} alasan tidak mendapat info dari $R T$ setempat.

Informasi indeksal: dituturkan oleh kader kepada ibu-ibu yang hadir bahwa ada beberapa orang yang tidak hadir dengan alasan tidak mendapat informasi.

Tuturan tersebut menyatakan bahwa penutur melaporkan bahwa ada beberapa ibu yang tidak datang dengan alasan tidak mendapat info dari RT setempat. Padahal, jadwal Posyandu sudah ditetapkan di awal pekan tiap bulannya. Jadi, alasan tersebut tidak bisa diterima lagi.

\section{c. Tindak Tutur Deklarasi}

Tindak tutur deklarasi yang ditemukan dalam penelitian ini dari segi fungsi ada tiga macam, yaitu (I) tindak tutur membenarkan, (2) tindak tutur melarang, dan (3) tindak tutur mengizinkan.

\section{1) Tindak Tutur Membenarkan}

Tindak tutur membenarkan ini dapat dilihat pada tuturan berikut.

(11) Ya, jadwal pemberian imunisasi dan vitamin masih sama seperti jadwal bulan lalu.

Informasi indeksal: dituturkan oleh kader kepada para ibu yang mengonfirmasi pernyataan seputar jadwal pemberian imunisasi.

Tindak tutur 10 menyatakan bahwa penutur membenarkan pendapat lawan tutur yang menyatakan bahwa jadwal pemberian imunisasi sama dengan bulan sebelumnya.

\section{2) Tindak Tutur Melarang}

Tindak tutur melarang yang digunakan kader Posyandu Mawar VII dan Posyandu Mawar IX 
Pademangan Barat Jakarta Utara ini dapat dilihat pada tuturan berikut.

(12) Eee..., belum selesai ya, ibu-ibu!

Informasi indeksal: dituturkan oleh kader kepada beberapa ibu yang berjalan meninggalkan Posyandu.

Tuturan tersebut adalah tindak tutur penutur yang bermaksud melarang para ibu meninggalkan Posyandu karena acara belum selesai.

\section{3) Tindak Tutur Mengizinkan}

Berikut tindak tutur mengizinkan yang digunakan kader Posyandu Mawar VII dan Posyandu Mawar IX Pademangan Barat Jakarta Utara.

(13) Ya, silakan!

Informasi indeksal: dituturkan oleh kader kepada para ibu yang hadir yang menyatakan bahwa giliran ibu tersebut menimbang anaknya dan berkonsultasi.

Tuturan I3 merupakan tindak tutur mengizinkan. Hal ini terlihat pada penanda kata silakan.

\section{d. Tindak Tutur Komisif}

Dari segi fungsi, tindak tutur komisif ditemukan dua macam dalam tuturan kader Posyandu Mawar VII dan Posyandu Mawar IX Pademangan Barat Jakarta Utara, yaitu (I) tindak tutur berjanji dan (2) tindak tutur mengancam.

\section{1) Tindak Tutur Berjanji}

Berikut tindak tutur berjanji yang digunakan kader Posyandu Mawar VII dan Posyandu Mawar IX Pademangan Barat Jakarta Utara.

(14) Bulan depan in syaa Allah akan ada petugas kesehatan dari Puskesmas.

Informasi indeksal: dituturkan oleh kader kepada semua ibu yang hadir bahwa bulan depan akan datang petugas kesehatan untuk memeriksa para balita.

Tuturan I4 tergolong tindak tutur berjanji karena penutur belum melakukan hal yang disebutkan dalam tuturannya.

\section{2) Tindak Tutur Mengancam}

Berikut tindak tutur mengancam yang digunakan kader dalam proses layanan informasi di Posyandu Mawar VII dan Posyandu Mawar IX Pademangan Barat Jakarta Utara.

(15) Ibu-ibu diperhatikan dan dicatat baikbaik, ya....apabila bulan depan tidak hadir maka putra-putri ibu tidak mendapat tambahan vitamin.

Informasi indeksal: dituturkan oleh kader kepada para ibu bahwa yang tidak hadir bulan depan tidak mendapat tambahan vitamin.
Pada tuturan tersebut penutur mengancam tidak akan memberikan vitamin tambahann bagi para ibu yang tidak datang bulan depan dengan alasan apapun.

\section{e. Tindak Tutur Ekspresif}

Ditinjau dari segi fungsi, tindak tutur ekspresif yang digunakan kader dalam proses layanan informasi dapat diklasifikasikan atas dua macam, yaitu (I) tindak tutur memuji dan (2) tindak tutur mengeluh.

\section{1) Tindak Tutur Memuji}

Tindak tutur memuji yang digunakan kader Posyandu Mawar VII dan Posyandu Mawar IX Pademangan Barat Jakarta Utara terlihat pada tuturan berikut.

(16) Ya, bagus!

Informasi indeksal: dituturkan oleh kader kepada ibu yang menanyakan kepada kader tersebut apakah jawaban dari pertanyaan kader tersebut betul.

Pada tuturan I6 penutur memuji jawaban yang diujarkan lawan tutur.

\section{2) Tindak Tutur Mengeluh}

Berikut tindak tutur mengeluh yang digunakan kader Posyandu Mawar VII dan Posyandu Mawar IX Pademangan Barat Jakarta Utara dalam proses layanan informasi.

(17) Aduh, kok jam segini baru datang, Bu?

Informasi indeksal: dituturkan secara tiba-tiba oleh kader ketika ada ibu yang datang sangat terlambat.

Tindak tutur tersebut digolongkan dalam tuturan mengeluh karena menyatakan keluhan penutur terhadap ibu yang datang tidak sesuai dengan waktu yang ditentukan. Hal ini ditandai dengan kata aduh yang menyatakan keluhan.

\section{Prinsip Kesantunan Kader dalam Proses \\ Layanan Informasi di Posyandu Mawar VII \\ dan Posyandu Mawar IX Pademangan Barat \\ Jakarta Utara}

Dalam penelitian ini, peneliti menemukan bahwa kader Posyandu Mawar VII dan Posyandu Mawar IX Pademangan Barat Jakarta Utara hanya menggunakan empat maksim, yaitu (I) maksim kearifan, (2) maksim kedermawanan, (3) maksim pujian, dan (4) maksim pemufakatan. Berdasarkan hasil analisis data, diperoleh peringkat pilihan cara yang digunakan kader tersebut untuk membentuk kesantunan berbahasa dalam proses layanan informasi. Maksim kearifan menduduki peringkat pertama dengan I42 tuturan (63,40\%). Dari I42 tuturan tersebut, 87 tuturan $(38,83 \%)$ dipandang santun dan 55 tuturan (24,55\%) dipandang kurang santun. Maksim kedermawanan menduduki 
peringkat kedua dengan jumlah tuturan 45 tuturan (20,09\%), sebanyak 30 tuturan (I3,39\%) dipandang santun dan I5 tuturan (6,69\%) dipandang kurang santun. Maksim pemufakatan menduduki peringkat ketiga dengan 29 tuturan (I2,94\%). Dari 29 tuturan tersebut, 25 tuturan (II,I6\%) dipandang santun, sedangkan 4 tuturan (I,78\%) dipandang kurang santun. Maksim pujian mendapat peringkat keempat dengan 8 tuturan (3,57\%). Untuk lebih jelasnya, hasil analisis data tentang prinsip kesantunan yang digunakan kader dalam proses layanan informasi di Posyandu Mawar VII dan Posyandu Mawar IX Pademangan Barat Jakarta Utara dapat dilihat pada Tabel 2.

Tabel 2. Tabulasi Kesantunan Kader dalam Proses Layanan Informasi di Posyandu Mawar VII dan Posyandu Mawar IX Pademangan Barat Jakarta Utara

\begin{tabular}{ccccc}
\hline & \multirow{2}{*}{ No.insip } & \multicolumn{2}{c}{ Skor } & \\
\cline { 3 - 4 } No. & $\begin{array}{c}\text { Kesantunan } \\
n n n n\end{array}$ & Santun & $\begin{array}{c}\text { Kurang } \\
\text { Santun }\end{array}$ & Jumlah \\
\hline I. & Maksim Kearifan & 87 tuturan & 57 tuturan & I42 tuturan \\
2. & Kedermawanan & 30 tuturan & 13 tuturan & 45 tuturan \\
3. & Maksim Pujian & 8 tuturan & - & 8 tuturan \\
4. & Maksim & 25 tuturan & 2 tuturan & 29 tuturan \\
& Pemufakatan & & & \\
& Jumlah & 150 tuturan & 74 tuturan & 224 tuturan \\
\hline
\end{tabular}

\section{a. Maksim Kearifan}

Tuturan-tuturan berikut ini merupakan contoh penerapan maksim kearifan oleh kader Posyandu Mawar VII dan Posyandu Mawar IX Pademangan Barat Jakarta Utara.

(18) Kalau tidak dimakan di sini, bubur kacang hijau boleh dibawa pulang.

Informasi indeksal: dituturkan oleh kader kepada para ibu yang tidak menyuapi anaknya di Posyandu.

Kesantunan tuturan tersebut dibentuk dengan kalimat komisif yang menyatakan penawaran. Penutur menawarkan kepada para ibu membawa pulang makanan sehat yang diberikan. Tuturan ini dipandang santun karena memerintah dengan kalimat berita lebih santun daripada dengan kalimat perintah.

\section{b. Maksim Kedermawanan}

Ujaran-ujaran berikut ini merupakan contoh penerapan maksim kedermawanan.

(19) Biar saya bantu pegang anak ibu, ya!

Informasi indeksal: dituturkan oleh kader kepada para ibu yang dihampirinya. Kader tersebut ingin membantu ibu yang sedang menimbang anaknya.

Tuturan tersebut dipandang lebih santun karena penutur memaksimalkan kerugian dirinya sendiri, penutur bersedia membantu. Selain itu, terdapat penanda kesantunan biar sehingga tuturan direktif menyarankan tersebut dipandang santun.

\section{c. Maksim Pemufakatan}

Ujaran-ujaran berikut ini merupakan penerapan maksim pemufakatan oleh kader Posyandu Mawar VII dan Posyandu Mawar IX Pademangan Barat Jakarta Utara.

(20) Ya, pilihan yang tepat untuk menu balita bulan depan.

Informasi indeksal: dituturkan oleh kader kepada para ibu yang mengemukakan jawaban dari soal yang sedang dibahas.

Tuturan deklarasi membenarkan tersebut dipandang santun karena kader tersebut sependapat dengan para ibu sehingga kecocokan di antara mereka maksimal.

\section{d. Maksim Pujian}

Ujaran berikut ini merupakan penerapan maksim pujian oleh kader Posyandu Mawar VII dan Posyandu Mawar IX Pademangan Barat Jakarta Utara.

(21) Wah, hebat... pintar ya anak ibu nggak cengeng!

Informasi indeksal: dituturkan oleh kader kepada ibu yang sedang menimbang anaknya.

Tuturan tersebut merupakan maksim pujian karena penutur memuji sikap ibu dan anak. Hal ini terlihat jelas dari kata yang digunakan, yaitu pintar.

\section{Tuturan yang Tidak Mematuhi Prinsip Kesantunan}

Dari data yang diperoleh, terdapat tuturan yang tidak mematuhi prinsip kesantunan.

Berikut contoh tuturan tersebut.

\section{(22) Hei, ibu-ibu!}

Informasi indeksal: dituturkan oleh kader kepada ibu-ibu yang ribut dan tidak tertib agar diam dan tertib.

Tuturan tersebut adalah tuturan direktif yang kasar. Si penutur bermaksud menyuruh para ibu untuk diam dengan cara bertutur samar-samar. Akan tetapi, pilihan kata yang digunakan tidak mematuhi prinsip kesantunan karena tidak memaksimalkan keuntungan lawan tutur malah akan membuat lawan tutur kecil hati.

\section{Simpulan}

Berdasarkan analisis data dan pembahasan, disimpulkan bahwa para kader Posyandu Mawar VII dan Posyandu Mawar IX Pademangan Barat Jakarta Utara santun dalam berbahasa. Hal tersebut berdasarkan temuan penelitian bahwa para kader dalam proses belajar mengajar di Posyandu Mawar 
VII dan Posyandu Mawar IX Pademangan Barat Jakarta Utara lebih banyak melakukan tindak tutur santun karena berdasarkan 224 tuturan, para kader dalam proses belajar mengajar di Posyandu Mawar VII dan Posyandu Mawar IX Pademangan Barat Jakarta Utara lebih banyak melakukan tindak tutur santun karena berdasarkan 224 tuturan, para kader menggunakan tindak tutur santun sebanyak I50 tuturan dan menggunakan tindak tutur kurang santun sebanyak 74 tuturan. Tuturan tersebut dituturkan dengan menggunakan tuturan direktif, representatif, komisif, ekspresif, dan deklarasi.

Kesantunan berbahasa bersentral pada jarak sosial, yang sekaligus mengatur tata krama berbahasa kita. Santun berarti tidak mengancam wajah, tidak menyatakan hal-hal yang bermuatan ancaman terhadap harga diri seseorang, atau tidak mencoreng wajah seseorang atau wajah diri sendiri. Melalui pembahasan dalam tulisan di atas, dapat kita simpulkan bahwa berbahasa santun itu sendiri merupakan kesadaran timbal-balik, bahwa kita senantiasa ingin mitra tutur kita berekspresi sebagaimana cara kita sebagai penutur berekspresi. Di lain sisi, teori kesantunan berbahasa juga menekankan agar kita senantiasa berekspresi sebagaimana kita ingin mitra tutur kita berekspresi terhadap diri kita. Temuan ini sangat penting dipahami oleh para kader. Diharapkan kepada kader tersebut agar memperhatikan kesantunan berbahasa dalam proses belajar mengajar. Hal ini disebabkan kader menjadi pusat perhatian para ibu dan masyarakat dalam bertindak tutur. Kader sangat besar pengaruhnya dalam membentuk kesantunan berbahasa.

\section{Persantunan}

Ucapan terima kasih kepada LPPM Universitas Indraprasta PGRI yang telah memberikan dukungan bantuan pendanaan kepada penulis. Tak lupa ucapan terima kasih kepada Jurnal Bahastra UAD yang telah memberikan kesempatan kepada kami.

\section{Daftar Pustaka}

Aziz, E. A. (2000). Refusing in Indonesian: Strategies and Politeness Implications. Disertasi, Australia: Monash University.
(2008). Horison Baru Teori Kesantunan Berbahasa: Membingkai yang Terserak, Menggugat yang Semu, Menuju Universalisme yang Hakiki. Pidato Pengukuhan Guru Besar, Indonesia: Universitas Pendidikan Indonesia.

Budiwati, T. R. (2017). "Kesantunan Berbahasa Mahasiswa dalam Berinteraksi dengan Dosen di Universitas Ahmad Dahlan: Analisis Pragmatik"-2017. www.lpp.uad.ac.id/wpcontent/uploads/2017/05/72.-tri-rina-budi557-57I.pdf

Gunarwan, A. (1994). "Pragmatik: Pandangan Mata Burung". Di dalam Mengiring Rekan Sejati: Festschrift Buat Pak Ton. Soenjono Dardjowidjojo. Hlm: 37—60. Jakarta: Universitas Atma Jaya.

Leech, G. (1993). Prinsip-Prinsip Pragmatik. Jakarta: Universitas Indonesia.

Markhamah, dkk. Analisis Kesalahan dan Kesantunan Berbahasa. Surakarta: Muhammadiyah University Press, 201 I.

Nordquist, R. "Pragmatics (Language). Glossary of Grammatical and Rhetorical Terms". Accessed on January I6, 2019 at 03.30 p.m. http://grammar.about.com/od/pq/g/prag maticsterm.htm

Uddin, A. (2012) "Strategi Kesantunan Berbahasa Indonesia Warga Kampus Universitas Jambi dalam Meminimalkan Paksaan kepada Petutur". http://journal.unbari.ac.id/index.php/JIP/arti cle/view/69

Rahardi, K. (2005). Pragmatik Kesantunan Imperatif Bahasa Indonesia. Jakarta: Erlangga.

Rustono. (I999). Pokok-pokok Pragmatik. Semarang: CV IKIP Semarang Press.

Syahrul. (2008). Pragmatik Kesantunan Berbahasa: Menyibak Fenomena Berbahasa Indonesia Guru dan Siswa. Padang: UNP Press.

Sofa. (20II). Tindak Tutur. http://massofa.wordpress.com/20II/0I/ 18/tindak-tutur, diunduh 12 Februari 2019).

Wijana, I.D.P. (1996). Dasar- Dasar Pragmatik. Yogyakarta: Andi Offset.

Wijaya, A. "Brown and Levinson's Politeness Strategies". 2015.

http://awinlanguage.blogspot.co.id/2013/ 0 5/brown-and-levinsons-politeness.html

Yule, G. (2006). Pragmatik. Yogyakarta: Pustaka Pelajar. 